\title{
STRESSFUL SITUATIONS IN LIFE, USE AND ABUSE OF ALCOHOL AND DRUGS BY ELDERLY IN MONTERREY, MEXICO
}

\author{
Bertha Alicia Alonso Castillo ${ }^{1}$ \\ Maria Helena Palucci Marziale ${ }^{2}$ \\ Maria Magdalena Alonso Castillo ${ }^{1}$ \\ Francisco Rafael Guzmán Facundo ${ }^{1}$ \\ Marco Vinicio Gómez Meza ${ }^{1}$
}

Alonso Castillo BA, Marziale MHP, Alonso Castillo MM, Guzmán Facundo FR, Gómez Meza MV. Stressful situations in life, use and abuse of alcohol and drugs by elderly in Monterrey, Mexico. Rev Latino-am Enfermagem 2008 maio-junho; 16(especial):509-16.

This is a descriptive, qualitative, and correlation study with 112 elderly aged 60 years or older. This study aimed to identify differences in alcohol consumption according to gender and marital status, and differences in the consumption of medical drugs by gender. It also aims to determine differences in stressful life events by gender, and differences in stressful life events associated to alcohol and medical drugs use and abuse, as well as to know their perceptions on the most stressful life events they have experienced. The results showed significant differences in alcohol consumption by gender $(U=154.0, p<0.01)$, in which the consumption was higher for men. It was reported that the medical drugs consumption $\left(\chi^{2}=5.95, p<0.15\right)$ and life stress indexes $(U=1038.5, p=0.10)$ are higher for women. The most stressful life events reported were: their health problems or those of their relatives, family and economic problems.

DESCRIPTORS: aged; alcohol drinking; stress

\section{SITUACIONES DE LA VIDA ESTRESANTES, USO Y ABUSO DE ALCOHOL Y DROGAS EN ADULTOS MAYORES DE MONTERREY, MÉXICO}

Estudio descriptivo correlacional con aproximación cualitativa de los datos en 112 adultos mayores de 60 años, con objeto de identificar las diferencias en el consumo de alcohol por sexo y estado marital y las diferencias en el consumo de drogas médicas por sexo, determinar los eventos de la vida estresantes que se asocian con el uso y abuso de alcohol y drogas médicas, y conocer las percepciones sobre los eventos de la vida que han experimentado como más estresantes. Los resultados mostraron diferencias significativas del consumo de alcohol de acuerdo al sexo $(U=154.0, p<.001)$, donde el consumo fue mayor para los hombres. Se reportó que el consumo de drogas médicas $\left(\chi^{2}=5.95, p<.015\right)$ y los índices de estrés de la vida $(U=1038.5$, $p=.010$ ) son mayores en las mujeres. Los eventos de la vida que percibieron más estresantes fueron; sus problemas de salud o de sus familiares, problemas familiares y económicos.

DESCRIPTORES: anciano; consumo de bebidas alcohólicas; estrés

\section{SITUAÇÕES ESTRESSANTES DE VIDA, USO E ABUSO DE ÁLCOOL E DROGAS EM IDOSOS DE MONTERREY, MÉXICO}

Estudo descritivo correlacional e abordagem qualitativa dos dados, realizado com 112 adultos maiores de 60 anos com o objetivo de identificar as diferenças no consumo de álcool por sexo e estado civil, identificar as diferenças do consumo de drogas médicas por sexo, determinar os eventos estressantes da vida que se associam com o uso e abuso de álcool e drogas médicas, e conhecer as percepções dos idosos sobre o que consideram eventos estressantes na vida. Os resultados mostraram diferenças significativas do consumo de álcool de acordo com sexo $(U=154.0, p<0,001)$, consumo foi muito maior para os homens. Reportou-se que o consumo de drogas médicas $\left(\chi^{2}=5.95, p<0,015\right)$ e os índices de estresse $(U=1038.5, p=.010)$ são maiores nas mulheres. Os eventos na vida que perceberam mais estressantes foram; seus problemas de saúde ou de seus familiares, problemas familiares e econômicos.

DESCRITORES: idosos; consumo de bebidas alcoólicas; estresse

${ }^{1}$ Faculty, Autonomous University at Nuevo León, School of Nursing, Mexico, e-mail: posgrado_enfermeria@terra.com.mx; ${ }^{2}$ Full Professor, University of São Paulo at Ribeirão Preto, College of Nursing, WHO Collaborating Centre for Nursing Research Development, Brazil, e-mail: marziale@eerp.usp.br 


\section{INTRODUCTION}

Alcohol abuse has become a health problem among the elderly, due to increased consumption and the effects on their health and quality of life. It is estimated that the use and abuse of alcohol in this population varies from $15 \%$ to $72 \%$ of the community, $2 \%$ in adults from Mexico who demand first level care and $25 \%$ of hospitalized patients ${ }^{(1-3)}$. The use of medical drugs, such as sedatives and hypnotics, was also reported in $16 \%$, psychotropic drugs in $33 \%$ and the combination of these drugs with alcohol in $12 \%$ of the elderly population, while $20 \%$ use a tranquilizer daily ${ }^{(4-6)}$.

The elderly are more vulnerable to the use of alcohol and drugs than the young. Among the factors which explain these differences are the decrease in muscle mass, body water and glomerular filtering of the elderly, since the level of substances and drugs soluble in water, such as alcohol, increase their blood level. Besides, there is an increase of interaction between alcohol and multiple medicines ${ }^{(3)}$.

We expect, in the next few years, to have an increase in this population segment due to the increase of life expectancy, and this could lead to a problem of greater proportions. However, the emphasis in literature, as well as the diagnosis and treatment, is mostly directed at adolescents and young adults. Thus, this problem tends to be underestimated and minimized in the elderly and, therefore, is not diagnosed. There are several reasons why the family and health care professionals do not detect or report this problem: the signals and symptoms are attributed to the other chronic diseases or to aging, being confounded with dementia or depression. Besides, health care professionals may consider it embarrassing to ask the elderly about the consumption of alcohol and drugs.

Some recent studies have observed gender differences in alcohol and medical drug consumption in the elderly population. It is reported that men tend to consume bigger amounts of alcohol than women, and also do it more frequently; regarding medical drugs, consumption is higher among women. Besides, stressing events in life were associated to the consumption of alcohol and medical drugs ${ }^{(7-10)}$.

The stressing events of life are derived from the unified concept about stress, agreeing that people adapt or adjustto the changes they experience in their environment. The argument is that there are multiple changes in life which are generated by these people's mature development stage, as well as those generated by interaction with meaningful others, and by the environment. These are evaluated cognitively as provocations, threats, damages or losses, which are confronted because they need to be overcome, leading to people's adjustment of accommodation ${ }^{(11)}$. The focus based on life events allows us to know how the elderly perceived facts and happenings that occurred along the last twelve months and which they found threatening, anguishing, preoccupying or stressing.

These facts, happenings or life events may threaten the person and include becoming a widower, getting a divorce, retiring, having economic problems, feeling abandoned and lonely, and this is probably when alcohol is consumed as a form of confrontation $^{(11)}$. Some studies ${ }^{(7-10)}$ report strong and significant relations, while others have not documented these relations. The authors of the present study have emphasized the need for a permanent analysis of these variables' behavior.

On the other hand, there are scarce studies which refer to the magnitude and possible factors associated to the consumption of alcohol and medical drugs by elderly in Mexico. The studies located so far show inconsistencies between the stressing variables of life and the consumption of alcohol and medical drugs, thus revealing a lack of knowledge on this theme. In this sense, this knowledge can serve as a basis for drafting primary and secondary prevention interventions and for reducing the consumption of alcohol and medical drugs among the elderly.

\section{OBJECTIVES}

- Identify differences in the consumption of alcohol by gender and marital status in the elderly;

- Identify differences in the consumption of medical drugs by gender in the elderly;

- Determine differences ing stressing events of life according to gender;

- Determine stressing events of life in the elderly associated to the use and abuse of alcohol and medical drugs;

- Get to know the perceptions of the elderly about the most stressful or preoccupying events in life they have experienced in the last twelve months and the role of alcohol consumption in these moments. 


\section{METHODS}

A quantitative study with a descriptive and correlation design was developed. This design was considered appropriate because it permits the observation, description and documentation of aspects of a situation which occurs naturally. A correlation design was chosen because two variables were associated, i.e. events of life and the consumption of alcohol and medical drugs. Thus, we have used a qualitative approach through a semi-structured interview and content analysis. The study sample consisted of 112 patients, men and women older than 60 , who went to the appointment over a three-month period. A systematic probability sample of one in three was used and the sample was obtained through the clinic's files. The sample size was calculated for an error limit estimated at $8 \%$, using a conservative focus, and adopting a $95 \%$ confidence level.

The inclusion criterion was that the participants were located in time, space and person through three questions: What day is today? What is your name? How did you come to the clinic? Later, the Pfeiffer instrument (SPMSQ-VE) ${ }^{(12)}$ was applied, which consists of ten reactive points, mainly aims to detect a possible cognitive deterioration and evaluates short-term memory. Literate elderly could have a maximum of two and illiterate participants a maximum of three errors on the Pfeiffer test.

Three instruments were applied, as well as a Personal Data Form and a semi-structured interview. The first instrument used was the Elders Life Stress Inventory $[\mathrm{ELSI}]^{(11,13)}$, aimed at measuring life stress by means of events the elderly has experienced during the last twelve months. The second instrument used to measure alcohol consumption by the elderly was the Michigan Alcoholism Screening Test - Geriatric [MAST-G] ${ }^{(14)}$. The third instrument was a Questionnaire to Evaluate the Consumption of Medical Drugs.

Finally, a semi-structured interview was held to find out how the elderly perceive the life events over the last twelve months which were stressful, preoccupying or dreadful and the role of alcohol consumption in these. In order to do so, a two-question interview script was built:

1) Which events from the last twelve months were the most stressful, preoccupying or dreadful?

2) What have you done to move on or to face these happening or events?

The study followed the Health Care Law Regulation in the Field of Health Research issued by the Mexican Ministry of Health. A favorable opinion was obtained from the Research Ethics Committee at the UANL Nursing College. Before beginning data collection, the elderly gave their informed consent for the application of the three instruments, as well as for the semi-structured interview.

The data were processed with Statistical Package for the Social Sciences (SPSS) software, version 11.0 for Windows. Descriptive and inferential statistics were used. Descriptive statistics obtained frequencies, proportions, core tendency and variability measures to describe the study variables. For inferential statistics, first, Kolmogorov-Smirnov's normality test was applied, followed by non-metrical tests. For the first objective, frequencies, proportions, Pearson's Chi Square test and Mann-Whitney's U-test were applied; for the second, Pearson's Chi Square test was applied; for the third, Mann-Whitney's U-test was used and, finally, for the fourth objective, Spearman's Correlation coefficient and MannWhitney's U-test were used.

Finally, for objective number five, a Word document was elaborated, based on the semistructured interviews, distributing the elderly people's narratives according to each question. Later, open coding was performed to identify the initial categories from the living codes, then returning to the document and again comparing the codes and initial categories. Finally, selective coding was carried out, establishing the final themes in this last analysis. The content derived from the interviews was presented, at first, by frequency and proportion tables of the theme categories the participants most frequently signaled.

\section{RESULTS}

Among the 112 elderly studied, $59.8 \%$ were women; $67.9 \%$ of the participants have finished basic education, which equals primary level. Participants were mostly married or lived with a fixed partner $(68.8 \%)$. The mean age was 68 years $(S D=5.81)$; regarding occupation, most do housework (51.8\%) or are retired $(31.3 \%)$.

In total, $37.5 \%$ (49 subjects) of the participants said they consume alcoholic drinks nowadays. A significant difference in current alcohol consumption was observed according to gender $\left(\chi^{2}=\right.$ $10.43 \mathrm{p}<0.01)$. Among women, $31.3 \%$ consume alcohol, while $62.2 \%$ of men report consuming alcoholic drinks nowadays. 
Table 1 - Kinds of current alcohol consumption among elderly by gender, according to the number of glasses

\begin{tabular}{lcccccccc}
\hline & \multicolumn{9}{c}{ Alcohol Consumption } & \multicolumn{2}{c}{ Total } \\
Gender & Moderate & \multicolumn{2}{c}{ Risky } & \multicolumn{2}{c}{ Abusive } & \multicolumn{2}{c}{ Tbu } \\
& $\mathbf{f}$ & $\%$ & $\mathbf{f}$ & $\%$ & $\mathbf{f}$ & $\%$ & $\mathbf{f}$ & $\%$ \\
\hline Female & 19 & 90.4 & 1 & 4.8 & 1 & 4.8 & 21 & 100 \\
Male & 8 & 28.6 & 12 & 42.8 & 8 & 28.6 & 28 & 100 \\
Total & 27 & 55.1 & 13 & 26.5 & 9 & 18.4 & 49 & 100 \\
\hline
\end{tabular}

Source: CDD and MAST-G $\chi^{2}=1 ., 61 ; \mathrm{p}<0.01$

Table 1 shows the current consumption of alcohol among the elderly, by gender, according to the number of glasses consumed on each occasion. The differences in the proportion of alcohol consumption according to gender are emphasized through Pearson's Chi Square test $\left(\chi^{2}=18.61 ; p\right.$ $<0.01)$. Besides, it is observed that women score higheron moderate consumption, while men tend to show more risky alcohol consumption.

Table 2 - Consumption and frequency of alcohol weighed by gender

\begin{tabular}{lcccc}
\hline \multicolumn{1}{c}{ Variable } & \multicolumn{4}{c}{ Gender } \\
& Female & \multicolumn{3}{c}{ Male } \\
& $\boldsymbol{f}$ & $\%$ & $\boldsymbol{f}$ & $\%$ \\
\hline $\begin{array}{l}\text { I. Have you consumed } \\
\text { alcoholic drinks in the past? } \\
\quad \text { Yes }\end{array}$ & 34 & 50.7 & 42 & 93.3 \\
$\quad$ No & 33 & 49.3 & 3 & 7.0 \\
$\begin{array}{l}\text { 2. How often did you } \\
\text { consume them? }\end{array}$ & & & & \\
$\quad$ Never & 33 & 49.3 & 3 & 6.7 \\
$\quad \begin{array}{l}\text { At least once a month } \\
\quad \text { Two or four times a }\end{array}$ & 29 & 43.3 & 4 & 8.9 \\
$\quad$ month & 3 & 4.5 & 18 & 40.0 \\
$\quad \begin{array}{l}\text { Two or three times a } \\
\text { week }\end{array}$ & 2 & 3.0 & 9 & 20.0 \\
$\quad \begin{array}{l}\text { Four or more times a } \\
\text { week }\end{array}$ & 0 & 0 & 11 & 24.4 \\
$\quad$ Daily & 0 & 0 & 0 & 0 \\
\hline
\end{tabular}

Source: MAST-G $* * \chi^{2}=22.38 p<0.01$

To broaden the explanation of the first objective, the MAST-G instrument was used. This has a cut-off point of about 5 points, which implies that, from this score on, there is alcohol abuse. In this instrument, the scores classify consumption as reasonable ( 0 to 1 point), risky ( 2 to 4 points) and abusive (more than 5 points). According to Table 2, differences in the classification of alcohol consumption are observed according to gender $\left(\chi^{2}=10.8 ; p=0.04\right)$, as women show a greater proportion of reasonable consumption, while men tend to show a bigger proportion in abusive alcohol consumption.
Table 3 - Mann-Whitney $U$ test for gender in current alcohol consumption

\begin{tabular}{lccccc}
\hline $\begin{array}{l}\text { Current alcohol } \\
\text { consumption }\end{array}$ & & & & & $P$ Value \\
& $\boldsymbol{n}$ & $\boldsymbol{D E}$ & $\boldsymbol{X}$ & $\boldsymbol{U}$ & \\
\hline Female & 21 & 2.60 & 0.99 & & \\
Male & 28 & 7.88 & 10.83 & & \\
\hline
\end{tabular}

Source: CDD and MAST-G

Table 3 shows the Mann-Whitney $U$ test for alcohol consumption (MAST-G) by gender, indicating a significant difference. The highest mean and median regarding alcohol consumption were found for the male gender. Then, Pearson's Chi Square test was applied for the type of alcohol consumption (MASTG) with marital status. However, the results did not show significant differences.

Regarding the consumption of medical drugs by gender in the elderly, it was noticed that more that $20 \%$ of women consume them, while only $4.4 \%$ of men reported this consumption, with a significant difference $\left(\chi^{2}=5.95, p=.015\right)$. Regarding the type of medical drug reported, tranquilizers (anxiolytics) are emphasized, with $83.5 \%$, and anti-depressants in $16.5 \%$. It is remarkable that, in more that $30 \%$ of cases, this class of drugs is obtained without prescription.

The Mann - Whitney $U$ test for life stress by gender indicated a significant difference. The averages and medians of stress indicate that women have a higher life stress index than men. According to the Spearman Correlation matrix, a significant relation was not found ( $r=-.166, p=.255)$ between stressing events in life and alcohol consumption. Besides, Mann - Whitney's $U$ test did not show differences in the relation between stressing events (ELSI) and the consumption of medical drugs (Ou=670.0, $p=.711$ ). On the other hand, the age when alcohol consumption started was positively related $(r=.290, p=.011)$ to the stress index, that is, the older the alcohol consumption started, the higher the life stress index.

The most stressing life events, which the elderly most frequently noticed, were: their own or their family's health problems (7 cases related to alcohol consumption); followed by family problems like separations, divorces, arguments and communication problems among family members; economic problems; the death of a family member and work problems. 
The study reveals that the activities the elderly carried out to face the stressing situations searched for social supports, among which family support $(60 \%)$, professional support $(35.6 \%)$ and church support (4.4\%) are emphasized. They mainly practice religious activities, such as: praying, asking God and having faith in God, besides having positive thoughts, pro-active activities, aimed at solving the situations, and recreational activities, such as: strolling around, watching TV, reading in order to forget. Alcohol consumption was not signaled as a confrontation resource for stressing life events.

\section{DISCUSSION}

The social-demographic profile of the elderly showed that the majority of people who received ophthalmological medical care and participated in the study were women with basic education level, and that most elderly lived with their partners. Regarding occupation, more than $50 \%$ took care oftheir homes. These characteristics are common for the elderly population in Mexico. Due to historical structural reasons, elderly people do not receive a pension, and only $31 \%$ of them have this right or a social security that protects them in this stage of life. This situation is evident by the fact that they depend on the children economically and live with them, which limits their independence ${ }^{(15-16)}$.

Regarding the first objective, the male elderly consume alcohol in greater amounts and more frequently than women, with significant differences, which coincides with reports from other studies in the same population ${ }^{(2,7-9)}$. These findings are similar to findings in other age groups in Mexico, since it is socially acceptable and culturally justified, and alcohol consumption by men and practices involving alcohol use by men are more open and manifested, while these practices involving women, on the other hand, are occult and moderate. Besides, excessive alcohol consumption in women, and this is also socially reproduced in this life stage ${ }^{(16-18)}$.

On the other hand, significant differences were also observed in the type of alcohol consumption. In the case of women, reasonable consumption was found for most women. Men also reported a high proportion of reasonable consumption, although less than women, followed by abusive consumption. These data coincide with other studies ${ }^{(2,16)}$, which indicate that, in this life stage, there is a tendency to decrease the ingestion of alcohol. This data on alcohol abuse is remarkable, since this study found greater alcohol abuse than a study with upper class elderly ${ }^{(9)}$ and with elderly needing primary health care care in Mexico City ${ }^{(2)}$

No significant difference was found in the type of alcohol consumption by marital status, although reasonable consumption is higher for the elderly who lived alone than for the ones who had a partner. Besides, risky and abusive consumption was higher for those who had a partner than for single participants. These data differ from the study with upper class elderly ${ }^{(9)}$.Some explanations for these differences probably occurred due to the economic situation of the study sample, who are of lower and average-low class, and to the fact that consumption may have explanations in terms of acquaintanceship with family and children, whom the elderly economically depend on and whom they live with.

According to the second objective, this study found that the consumption of medical drugs was higher in female than in male elderly, which coincides with other Mexican studies ${ }^{(9,16)}$. The most consumed medical drugs include tranquilizers (anxiolyticss) and anti-depressants, which probably is related to the health culture of women who, due to the caregiving role in the family, are more prone to the consumption of medicine than men.

Still, this consumption of medical drugs can be related to the presence of insomnia and emotional states of depression, anxiety and stress, symptoms that are common in this life stage ${ }^{(9-16)}$. What draws attention is that more than $30 \%$ of them can get or buy this drug without prescription, which is regulated by the Health Sector. This indicates a probable lack of supervision in the control of these medicines.

The higher prevalence of chronic diseases among the elderly, such as systemic arterial hypertension, implies increased medicine consumption. As a consequence, the incidence of problems related to medicines increases, leaving the population vulnerable to several health problems ${ }^{(17)}$.

Regarding the third objective, it is important to emphasize that there are significant differences in the stressing events of life by gender, with higher perception levels of these events among women than among men. This coincides with upper class residents ${ }^{(9)}$, where women reported greater perception of life stress than men. This fact can also 
be explained by the fact that, culturally, in Mexico, and in other traditional Western societies, women have a very important role as mediators of family problems and source of social support for children, partner and other relatives, thus increasing the perception of really preoccupying life events.

In the same sense, the life events the elderly reported more frequently and as the most stressing ${ }^{(11)}$ were, in the first place, memory deterioration, followed by financial situation deterioration, alterations in family health or behavior, presence of a disease or injury and impossibility to practice activities they used to enjoy a lot. As observed, some of these events are related to the changes brought about by aging ${ }^{(18)}$, which limits their lives, capabilities and makes them dependent on family and friends, with the aggravator of not counting on social and economic support means or government mechanisms, which could help them face this life stage with dignity.

Regarding the fourth objective, no significant relation was found between stressing life events and current alcohol consumption. This finding is similar to studies carried out in Mexico and the USA ${ }^{(7,9,13)}$, but contrary to studies that reported the effect of stressing events and alcohol consumption. This finding is probably explained by the fact that average alcohol consumption and stressing events were low and that the elderly are probably using other healthier ways of confronting stress ${ }^{(8)}$.

Similarly, no significant differences were found regarding medical drugs and stressing events, in line with one study ${ }^{(9)}$, but different from another ${ }^{(10)}$. A significant difference was not reported in this study because average drug consumption levels were low. This finding can partially be explained by the cost of controlled medicines and by the fact that less than half of the elderly count on social security, which would allow them to get more medicines.

However, there was a positive and significant association between the life stress rate and age of alcohol consumption onset, which indicates that, the older they start consuming the substance, the greater the perception of stressing life events. This finding shows that elderly who start getting involved with this practice later in their youth had a greater probability of perceiving more stress in this stage of life. This probably indicates that the subjects learned social abilities when they were young or that healthier ways of confronting life were reinforced, which shows the need for more analysis and study to know about elderly people's subjectivity, the meaning of stressing life events and alcohol consumption.
In order to respond to objective number five, it was qualitatively documented that the perception of the elderly about those events in their life which they experienced as most stressful, in the last twelve months, was very similar to what was identified by the ELSI questionnaire ${ }^{(11)}$. The most stressing or preoccupying events, defined qualitatively, include, in the first place, the elderly's health problems, e.g. suffering from type 2 diabetes mellitus, Parkinson's disease, arterial hypertension, cerebrovascular accident, diseases which decrease their visual accuracy and heart problems, as well as the disease of a family member, especially alcoholism problems in some of their children.

Secondly, family problems were emphasized, among which divorces, arguments and communication problems between the couple and with children stood out. In the third place, economic problems were identified, with difficulties to have little money to survive or have the responsibility to financially support their grandchildren, abandoned by their children. As observed, the elderly keep facing several concerns and problems deriving from their family role in this stage of life since, in most cases, these problems are related to their children and grandchildren, with the aggravator of being sick and not having economic means to help.

In order to broaden the explanations about how the elderly confront the stressing life events and the role of alcohol consumption, they indicated the use of distinct mechanisms, such as looking for social support like the support offered by NGOs, such as the Vidaurri Eye Foundation, the International Lions Club, Monterrey Caritas and some governmental organizations. Another strategy that is used is the support of religious beliefs, praying and having faith in God. Finally, they pointed out that they intentionally have positive thoughts that help them face their problems. However, the consumption of alcohol was not indicated as a confrontation resource.

These findings allow for broader explanations, because a relation between these events and the consumption of alcohol was not found. Alcohol consumption is probably associated to socialization practices and other negative emotional states which require study. As mentioned above, the elderly use diverse confrontation mechanisms, which their experience and life allow them to develop. Therefore, alcohol consumption has a distinct meaning that must be studied. 


\section{CONCLUSIONS}

The consumption of alcohol by gender was significantly different, with higher consumption by male elderly. No significant differences were found regarding the consumption of alcohol according to marital status.

The consumption of medical drugs was significantly different, with higher levels among the female participants. The most consumed drugs were tranquilizers (anxiolyticss) and anti-depressants.

The presence of significant differences in stressing life events by gender stands out, with a higher perception of these events by women.

The most important stressing events were memory deterioration, followed by the deterioration of the financial situation, and alterations in a family member's health or attitude. No significant difference was found regarding stressing life events and the consumption of alcohol. However, there was a positive and significant relation between the life stress rate and the age of alcohol consumption onset. No significant differences were found regarding stressing life events and the consumption of medical drugs.

The most stressing or preoccupying events which the elderly qualitatively pointed out were similar to the ones already identified: in the first place, their health problems, such as a family member's disease, among which alcoholism of one of their children stands out; in the second place, the family problems, with emphasis on divorce, arguments and communication problems between the couple or with their children. Thirdly, economic problems were identified, such as difficulties to count on what is necessary to survive and having the responsibility to economically support their grandchildren, in view of abandonment by their children.

\section{REFERENCES}

1. Castro MA. El adulto mayor y los riesgos de adicción. Higiene: Rev de Salud Pública 1997; 5(2):41-5.

2. Solís LR, Vélez A, Berúmen D. Prevalencia del consumo de bebidas alcohólicas y problemas asociados en personas de la tercera edad que acuden a los servicios de atención primaria de la ciudad de México. Salud Mental 2000; 23(3):38-45.

3. Levin SM, Kruger L. Substance abuse among older adults: A guide for social service providers. In: Rockville MD. Substance abuse and Mental Health Services Administration; 2000 .

4. Zisserson RN, Oslin DW. Alcoholism and at-risk drinking in the older population. Geriatric Times 2003; 4(5):128-35 5. Hulse GK. Alcohol, drugs and much more in later life. Rev Bras Psiquiatría 2002: 24(1):34-41.
The activities the elderly acknowledge to use in order to confront these stressing life events were searching for social support, sticking to their religious beliefs and having positive thoughts. The consumption of alcohol was not reported as an activity or resource for confronting the stressing life events.

Further studies are needed on the consumption of alcohol and medical drugs in elderly people, incorporating other emotional states, such as depression, angst and anxiety. Moreover, the construction of the meaning of alcohol consumption in this age group should be elaborated in qualitative terms and intervention studies are needed about the manipulation of social abilities as mechanisms used to confront stress in elderly.

\section{ACKNOWLEDGEMENTS}

Acknowledgements to the Inter-American Drug Abuse Control Commission/CICAD of the SubSecretary of Multidimensional Security at the Organization of American States/OAS, the Brazilian Anti-Drugs Secretary/SENAD, faculty members at the University of São Paulo at Ribeirão Preto College of Nursing, WHO Collaborating Centre for Nursing Research Development, Brazil, to the population who participated in the studies and to the representatives from eight Latin-American countries who participated in the I and II On-Line Specialization Program for Research Capacity-Building on the Drugs Phenomenon-PREINVEST, offered in $2005 / 2006$ by the University of São Paulo at Ribeirão Preto College of Nursing, as a distance education course.

6. Connell H, Ai-Vym C, Cunninghan C, Lawlor B. Alcohol use disorders in elderly. People-redefining age old problem old Age. $\mathrm{Br}$ Med Journal 2003; 327(7,416): 664-9.

7. La Greca AJ, Akers RL, Dwyer JW. Life Events and Alcohol Behavior among Older Adults. Gerontolo Soc Am 1988; 28(4):552-8.

8. Glass TA, Prigerson $\mathrm{H}$, Kasl SV, Mendes de Leon CF. The effects of negative life events on alcohol consumption among older men and women. Geronto 1995; 50(Health Modules):S205-S16.

9. Garza RI. Estrés de la vida y su relación con el consumo de alcohol y drogas médica en adultos mayores[Tesis de maestría]. Monterrey (N.L): Universidad Autónoma de Nuevo León, México; 2005.

10. Frone M, Cooper ML, Russel M. Situaciones Estresantes de la Vida y Uso de Substancias, Psycholo Addictive Behav $1994 ; 8(2): 59-69$. 
11. Aldwin CM. The Elders Life Stress Inventory (ELSI): Egocentric and non egocentric stress. Stress Later-Life Families 1990:49-694.

12. Martínez J, Dueñas R, Onis MC, Aguado C, Albert C, Luque R. Adaptación y validación al castellano del cuestionario de Pfeiffer (SPMSQ) para detectar la existencia de deterioro cognitivo en personas mayores de 65 años. Med Clín 2001; $117(4): 129-34$.

13. Welte JW, Mirand AL. Drinking, problem drinking and life stressors in the elderly general population. Studies Alcohol 1993; 56:67-73.

14. Blow FC, Brower KJ, Schulenberg JE, Demo-Dananberg LM, Young JP, Beresford TP. (). The Michigan alcoholism screening test-geriatric version (MAST-G): A new elderlyspecific screening instrument. Alcoholism: Clin Exp Res 1992; 16: 372.

15. Instituto Nacional de Estadística, Geografía e Informática [INEGI] (MX) .Estratificación por AGEB del área metropolitana de Monterrey según nivel de bienestar. Nuevo León; 2005

16. Tapia R. Las adicciones: dimensión, impacto y perspectivas. 2a ed. México (D.F): Manual Moderno; 2001. 17. Lyra DP Júnior, Amaral RT, Veiga EV, Cárnio EC, Nogueira MS, Pelá IR. A farmacoterapia no idoso: revisão sobre a abordagem multiprofissional no controle da hipertensão arterial sistêmica. Rev. Latino-am. Enferm. [periódico na Internet]. 2006 Jun; 14(3): 435-441. Disponível em: http:/ /www.scielo.br/scielo.php.

18. Ravelo BP. Representaciones y prácticas de alcoholización femenina: experiencias de un grupo de obreras del vestido en Análisis Cualitativo en Salud. Teoría, Método y Practica. México (D.F): Plaza Valdés Editores; 2000. 